\title{
Ernst Jünger, total mobilisation and the work of war
}

\author{
Bogdan Costea and Kostas Amiridis
}

Lancaster University, UK

\begin{abstract}
This review article explores three interconnected texts written in the 1920s and 1930s by the German intellectual Ernst Jünger: Copse 125, Total Mobilisation and The Worker. Dominion and Form. They contain his original analyses of the relationship between war, destruction, organisation and technology. Jünger argued that entering the realm of total organisation, that is, organisation which claims its ground to be scientific, calculated, planned, rationally-administered and technological, destruction is subtly appropriated into, and thought of, as a process of production. Jünger understood war as an increasingly 'necessary' and permanent requirement of the politics of peace and freedom. He anticipated the transformation of destruction into a major field of experimentation with, and through, complex state and private organisational networks (civilian, military and corporate), and into a prime arena of scientific, technological and managerial development. $\mathrm{He}$ analysed the emergence of new political discourses and systems whose common ground was to invoke permanent insecurity, risks and dangers and claim the need to manage the peaceful existence of liberal societies.
\end{abstract}

\section{Keywords}

Danger, freedom, organisation, power, risk, security, technology

\section{Introduction}

This review article introduces to scholars of organisation studies three works by Ernst Jünger (1895-1998), one of Germany's most celebrated writers on war in the 20th century: the volume of war diaries entitled Copse 125, from the summer of 1918 (Jünger, 1930a); the essay Total Mobilisation, from 1930 (Jünger, 1930b); and the major synthesis of 1932, The Worker. Dominion and Form (Jünger, 1981). Writing nearly a century ago, Jünger would have understood, 
and greeted most enthusiastically, the thematic of this special issue. How might his analyses still be relevant today when war seems to have changed so much and in so many ways? The answer comes from the congruence of his concerns with those of this special issue. He was interested in how military, political, economic and scientific agencies had formed a new alliance that brought war under the sign of technological, organisational and scientific mobilisation. Equally central was the question of the expansion of war's spatial reach to become truly 'planetary' both in physical and in political terms. He wrote, in a brief note added in 1980 to Total Mobilisation, that 'The rearming of the world powers has attained planetary weight; to it corresponds the potential of all armament' (Jünger, 2015: 142). He too was preoccupied by the changing ethos of war both in macro-political terms and in the minute details accompanying the new relationship between humans and machines which was rendering war into technologically-driven work. Also, he saw the increasing danger of war deriving from the appropriation of destruction under the spell of a specifically modern and unparalleled confidence in the rationality of mass-production, technological progress and their cor- responding managerial processes and organisational forms.

A recent instance showing the affinity of Jünger's analyses with current events and concerns emerged in a discussion at a panel at the annual meeting of the Association of the US Army in Washington, on 4 October 2016. Addressing the possibility of direct conflict among military super- powers, two of United States' top commanders (Lt. Gen. Joseph Anderson, deputy chief of staff for operations, plans and training, and his deputy, Maj. Gen. William Hix) argued that such a conflict (between the United States, Russia and China) would be 'lethal and fast' - and the 'stopwatch' would not be under control. Considering the possibility of a ground war accelerated by artificial intelligence and precision weapons, Maj. Gen. Hix explained that

The speed of events is likely to strain our human abilities. The speed at which machines can make decisions in the future is likely to challenge our ability to cope, demanding a new relationship between man and machine. (Defense One, 2016)

The similarity between these comments and Jünger's analyses is significant. Witnessing the wholesale annihilation and self-mutilation which first befell Europe a century ago, he understood that its sources point to deeper and more disturbing historical processes. For him, that war brought to the fore the same enchantment with power expressed in the will to the technological acceleration of organised destruction we witness even more emphatically today. What struck Jünger, perhaps more than anything else in World War I (WWI), was the way in which the relentless pursuit of destructive power was turning technology into a self-destructive force against its very creators who remained unable to understand 
what was unfolding through their own actions. He notes, in diaries from 1918,

No - war is not a material matter. There are higher realities to which it is subject. When two civilized peoples confront one another, there is more in the scales than explosives and steel. All that either holds of any weight is in the balance. Values are tested in comparison with which the brutality of the means must - to anyone who has the power to judge - appear insignificant. A strength of will, all-embracing and concentrated to the last pitch in the highest untamed expression of life asserting itself even in its own annihilation, is brought into play. (Jünger, 1930a: ix-x)

WWI was fought not only between armies but also between the systems of modern science, engineering and production. Machines had triumphed, and in the name of their 'rational power', human life could be blindly gambled away. Jünger recognised the formation of what President Eisenhower would call, in 1961, 'military-industrial complexes'. He thus turned his attention to an organisational analysis of war: what happens when it becomes a planned, calculated, organised, work-like 'performance', an enterprise to be administered with minimal exertion and risk to one's own 'assets', whose operations and processes are to be executed with 'surgical precision', from a distance and preferably with means that overcome limitations of physical geography - features of military work recognisable a century later? The answer, truly frightening to Jünger, was that war is transformed into an instrument integral to the arsenal of peace itself, inextricable from the continu- ous expansion of organisation and order, of security, and thus a necessary guarantee of 'universal freedom'.

In 1970, the philosopher George Steiner wrote that

Ernst Jünger came nearer than any other writer, nearer even than the poets, to forcing language into the mould of total war. ... The chaotic hell of the Somme and Langemarck grew into more than a searing memory or an instance of life turned lunatic. The fire-storm of the big guns, the moon-landscape of craters and flares, the somnambular frenzies of hand-to-hand fighting, seemed to Jünger to compact certain essential truths and mysteries in man. After such battle there could be no peace, only an armistice. (In Jünger, 1970: 7)

This is not a simple compliment: Steiner captures the direction of Jünger's works about war. In this sense, WWI had been only a fragment of what was to come. War was not incongruent with the expansionist economic and political tendencies of global powers. And the most frightful aspect was its new political legitimation: war should be left to reason, technology and their progress as the ultimate defenders of freedom.

Jünger saw WWI as the threshold of a new age of belligerence, the inauguration of 'nothing short [than] a century of death' (Malesevic, 2010: 120). 
'The war that will end war', as H. G. Wells (1914) wished it, had been but 'the war that ended peace', as Margaret MacMillan (2013) argued a century later. For Jünger, the war of a century ago was a sign of Friedrich Nietzsche's (2005) uncanny diagnosis, in 1888, that modernity will enter a phase in which 'there will be wars such as the earth has never seen' (p. 144). Instead of an empty prophecy, for Jünger this was an insight into the indissoluble bond taking shape between the central promises of modern individualism and of Liberalism (promises of security, freedom and unlimited self-assertion) and the permanent mobili- sation of war against any imaginable danger (or risk) that might threaten them.

In this sense, as part of his emerging critique of bourgeois liberalism and modernity, Jünger's writings about WWI differ from its mainstream poetic and metaphysical interpretations. For most authors, the slaughter could have had only one meaning: to reveal that war was an alien, aberrant, event in the history of civilised, modern, indeed humanistic, Europe. While Jünger dwells, like others, on the macabre imagery of destruction, mutilation and death, unlike theirs, his visions are harder to decipher. For one thing, his profound indignation with technological death and its claims to rational organisation are expressed in almost heartless, cold and detailed descriptions. Moreover, there grows in parallel a complex imagery of the cosmic relevance of war: being under fire gener- ates an atmosphere of dramatic intoxication, an eruption of powers in which humanity reveals its demonic capacity to engage with elemental forces. For Jünger, war is a discovery in which he revels because it seems to offer a spectacle of the forges and workshops in which history itself is being stamped out and synthesised in a clearer expression than peace can offer. At times, there is no human community left, for him, other than in the monumental and devastating suffering of the trenches. An ambiguous aesthetics of heroic death seems to haunt Jünger's writings, and Walter Benjamin (1979a, 1979b) seized it in his review of War and Warrior, in 1930, pointing out that the mystification of war was coming dangerously close to the imagery of emerging Fascist ideologies, even though he had himself been impressed by Jünger's war diaries and deployed similar images in short writings of the 1920s (Benjamin, 1979a: 103-104). In the event, Jünger never became a fascist or a national-socialist; to the contrary, he rejected all the advances of the Nazis to join their movement, extensively documented by Jünger scholars such as Paetel (1949), Hervier (1978, 2014) and Kiesel (2007). But he remained, at the same time and like so many German intellectuals at the time, a patriot and fervent critic of the German humiliation at Versailles and the Weimar regime's incapacity to govern.

Jünger's stark and uncomfortable vision of war admits perhaps a different kind of analogy: one between his texts and Francisco Goya's paintings and drawings of the Spanish Civil War a century earlier (in works between 1808 and 1812) and of the cultural decadence of Europe in the Black Paintings for the period 1819- 
1823. Akin to Goya's visions of the brutality and certainty of fini- tude in Saturn Devouring His Son and of decadence in The Pilgrimage to San Isidro, Jünger's vision of war and its place in modern culture was also driven by a sense of its inevitable recurrence, echoing that of Nietzsche (1968) who, concluding a note of 1888, wrote, 'life itself is a conse- quence of war, society itself a means to war' (p. 33). Jünger went further: having experienced a war of the kind Nietzsche anticipated, he recognised, both in it and in Nietzsche's thinking, the philosophical heritage of one of the founders of Western thought, Heraclitus:

One must realize that war is shared and Conflict is Justice, and that all things come to pass and are ordained in accordance with conflict. (Heraclitus of Ephesus, 1979: 66-67, Fragment LXXXII)

He returned frequently to Heraclitus' fragments on war because he understood them not as pointing to an inherent belligerent instinct. For him, Heraclitus does not praise war but rather clari- fies the most pressing question about it: how does war reflect those historical moments when social, political and cultural orders fail to grasp that their self-assurance has crossed the threshold towards hubris, and the limits of a certain system of values have been reached?

\section{Copse 125: the soldier as 'worker of destruction'1}

Jünger spent 1351 of the 1547 days of the war in the trenches where he kept copious, detailed, notes and diaries covering 567 days, in their vast majority, days of battle (Schöning, 2014: 42). Copse 125 (subtitled A Chronicle from the Trenches of 1918) followed his famous In Storms of Steel (cov- ering the period of the Somme battles - Jünger, 1930d, 2003b). However, Copse 125 is not strictly a battle diary; it covers about six weeks of relative calm in the summer. His company had been ordered to defend a small piece of land around a small copse of trees ('Bois du Rossignol' on civil- ian maps), near a village in Belgium:

It had not the least strategic importance, and yet at that time it had a meaning for all Europe as a local symbol of power where many lines of fate intersected, and against which were set in motion a strength in men and machinery that could have reclaimed a whole province. Hence it is well worth while to make it the point of a survey whose aim it is to reach beyond the episodal to the universal. (Jünger, 1930a: xi)

Although a complicated task, he combines these levels of analysis with ease, operating beyond 'political' commentaries or lamentations. Instead, Jünger seems to have retained a measure of san- ity by connecting daily trench life to the wider, deeper transformations represented by the war. The analysis is based on 
observations of the central characteristics of war in transformation. The first theme is technology, 'the triumphal march of the machine' (Jünger, 2001: 53). The second is the changed space of war through the excessive growth of destructive power over physical distance, transforming the geometry of military strategy away from seeking direct engagement with the enemy in battle, towards seeking the enemy's sheer annihilation with minimal engagement. Third, central for Jünger was the re-organisation of the human subject at war into a mere extension servic- ing mechanical power, a phenomenon understood more profoundly by soldiers than by their commanders. They saw their humanity erased from the calculations of strategists and specialists who instead asked for more and more factory-produced death through machines of unprecedented annihilation. Assaulted continuously from every angle, soldiers knew that they had become merely another form of material, another kind of military consumption to be expended as required. By 1917-1918, decisions to go over the parapets were increasingly based on risk calculations deter- mined by artillery fire and distances:

It was as if, when coming out of the trenches, we knew exactly what was waiting for us. Because danger appeared like a mathematical formula - ascertained and calculated like everything related to the machine. (Jünger, 1929: 27)

As he was recording the details of the organisation and management of war, Jünger began to trace how the relationship between technology and power was being reconfigured around the pri- macy of a cold ethics of calculation in which industrial production was becoming a decisive agency of destruction. He therefore also understood that industrialised war was not simply an interruption of the 'long peace' and of the 'Concert of Europe' (following the Congress of Vienna in 1815). Rather, war expressed the same expansionist yearning for power, that 'permanent and supreme aim of [modern] politics', as Arendt (1946: 601) argued in her reflections after World War II (WWII). Analysing technology beyond its material appearances, following Nietzsche's conception of the 'will to power', war revealed a much deeper transformation of the conception of human power and mastery over the world:

In order to understand this, one must have a clear conception of the nature of machinery. It is an expression of the human will to master matter. We see every day in all branches of industry how a new miracle of mind fused into steel abolishes at a stroke all that has gone before. There is no pause. All is movement, pushing relentlessly and madly forward. (Jünger, 1930a: 134)

Mastery over the world through machines was integral to modernity as a 
Western project: 'To assemble immense energy in a small space and with it to conquer distance - such is the expression of our will to power' (Jünger, 1930a). And yet, the more strategists relied on the sheer mass of firepower as decisive, the more battles stalled and fronts came to a standstill. The experiences on the Somme had shown how the mere possession of increasing amounts of firepower was not going to be decisive; on the contrary, the possession of pure mechanical fire, while appearing to provide flexibility in its deployment, actually had the opposite effect:

Here we had the picture of the great battle of automata which consists in this - that two strongly organized and yet at all points highly mobile zones of power, whose molten edges flow into one another, attempted to turn each other from an ordered array into a chaos of useless iron and enervated mobs. (Jünger, 1930a: 24)

Copse 125 analyses, from the frontline, the new alignment between production and destruction, and the shift of military decision and organisation towards the primacy of technological systems. Incapable of seeing the one-sidedness of this calculus, military commanders demanded that states mobilise their entire systems of industrial production for the continuous accumulation of fire- power. Defying all the laws of military economy, technological power could only bring about a paralysis of the frontlines, as well as exhausting the human energy and will to fight. Jünger grasps that something new had emerged from these endless battles of material. He shows how the domina- tion of technological death had begun to change the ethos of war among soldiers. In permanent danger of being simply used up in the consumption of raw materials for the production of mechanical destruction, they understood the historical essence of the war; they no longer saw themselves as soldiers, but as machine operators, as workers claimed by the mechanical logic of a line of production akin to that of the factories manufacturing these infernal devices. By the summer of 1918, they all knew that the war's

... length as well as the unimagined violence of its phenomena made far more and quite other demands on our powers of endurance in body, soul, and spirit than we had foreseen. Months became years, and the pomp of battle a daily round of hard work. But at the same time the war, too, became a usual instead of an unusual state of affairs and dug itself permanently into us. (Jünger, 1930a: viii)

They had become 'long since habituated to an existence that made the utmost possible demands, and was already inwardly and outwardly set in that mould that answers to a new age and its new methods' (Jünger, 1930a: $\mathrm{x}$-xi). Technological war had forged a type of 'soldier-worker' 'such as before could never have been 
dreamt of':

It arose when the spirit of the machine took possession even of the battlefields of Europe, and the flying man and the man in the tank and the scientifically trained leader of the raid squad appeared. (Jünger, 1930a: 3)

However, as battle acquired the character of technologically-driven work, Jünger maps a change in soldiers' experience of themselves. Fear of the distant and continuous assault of the machines began to combine with an instinctive understanding that a new kind of agency had become avail- able to each of them. If a soldier could comprehend the logic of the machines, it would bestow not simply flexibility and 'readiness' for effective reaction, but would also allow a rapid work-like fusion of human skill with technology and its requirements. He wrote, in a shorter sketch based on his diaries,

We have to transfer what lies inside us onto the machine. That includes the distance and ice-cold mind that transforms the moving lightning stroke of blood into a conscious and logical performance. What would these iron weapons that were directed against the universe be if our nerves had not been intertwined with them and if our blood didn't flow around every axle? (Jünger, 1929: 84)

This was a sign of a future transformation: soldiers becoming total fighting units, ready to be deployed within an organised system of pure apparata, driven by centralised decision-making based on criteria of pure technological rationality. The new soldier is not a warrior, but a technical operator, a mechanical specialist, capable of understanding both how instruments are made and how they are to be used. 'All turns', Jünger (1930a) wrote, 'on mobility, effective fire, and protec- tion; [...] on propulsion, automatic fire, armament. To these must be added changing requirements such as noiselessness, camouflage, protection against gas, wireless communications, and a hun- dred more' (p. 132). This prescient observation of the re-organisation of combat in its most minute details offers one of the earliest characterisations of combat operations now recognisable, in retro- spect, in the wars of the 20th and 21st centuries. The aim of engagement in battle is not to die as a hero; the heroic no longer lies in personal sacrifice. The true achievement is mastery of the techno- logical means for the destruction of the inimical 'other'.

Technology and its logic had changed war irrevocably. As a consequence, one of the fundamen- tal transformations he anticipated was that of the spaces of war, in terms of the shape of localised theatres of operation, but also of strategic regional and global penetration of technological war. Instead of fixed lines, 'The right [image of combat] is that of a network into which the enemy may certainly 
penetrate here and there, but where he will at once be overwhelmed from all sides by a web of fire' (Jünger, 1930a: 23). The image of a 'network', or 'web', captured the new organisation of military work: 'It is a question no longer of launching men in mass, but machines - that is to say, death in a concentrated form that only yesterday put at our disposal' (Jünger, 1930a: 130). A novel combination of devices had rendered the fixed spaces of battle obsolete: the first systematic use of automatic rapid-fire weaponry on a mass-scale; the obsessive increase in the power, distance and strategic authority of artillery; the use of poison gas (despite the Hague agreements of 1899 and 1907) as a means of mass-destruction; and the emergence of tanks and aviation (however primi- tive) as new means of movement.

For Jünger, it was not the novelty of each of these instruments that gave them their significance (apart from tanks, all had already established histories he understood well). It was the coordination of systems of such weapons that was becoming decisive and against which only a new kind of organisation could offer a chance of survival. Thus emerged raid, or shock, patrols (Stoßtruppen, introduced by the German army in 1915, and adopted by all parties on the Western fronts by 1917): small commandoes infiltrating static lines through rapid and stealthy movement, using portable machine guns and grenades, supported by unreachable heavy artillery. Jünger realised that this would be the only role of direct human involvement in future technological wars, a feature clearer today when combat unfolds almost exclusively in this form: interventions driven by air power from remote, centrally organised platforms on land or sea, using increasingly unmanned, remotely-con- trolled means. Human intervention tends to be reduced to special forces deployed in small (and, preferably, secret) teams in preparation for air strikes, followed by patrols operating from strictly delimited local bases when technological options against guerrillas in urban and civilian centres, or difficult terrain, are exhausted. This form of combat has become central to the comprehensive US and UK military doctrines in 2013 and 2014: the core principles are those of overwhelming offensive power, to be supported by shock commando action, flexible, mobile, under central com- mand (Chief of the Defence Staff, 2014; Joint Publication 1, 2013). The political failure of military campaigns in the last two decades has made the deployment of soldiers an even less viable option; it is therefore likely that this manner of combat will continue to feature as central to official mili- tary doctrine.

Copse 125 remains remarkably contemporary, especially at a time of conflicts originating in the permanent urgency of the global 'war on terror', when interests are never simple, or 'local'. The growth of the technological basis of war and of highly complex systems for the organisation of concrete operations by weaponry whose range and intent are inherently 'planetary' (especially as direct human intervention is increasingly taking place at a distance, through the operation 
of drones, or long-range missile systems, for example) are features whose genealogy merits revisiting from the perspective of organisational analysis.

\section{Total mobilisation and the consolidation of war as 'public good'}

Published in a collection of studies edited by Jünger (1930c) himself, Total Mobilisation is an attempt to understand the transformation of the body-politic of the state in the vacuum left by the disintegration of monarchic systems in Europe and Asia. ${ }^{2}$ Was the 'wasteland' left in the war's wake as barren as it seemed? For Jünger, its outcome was the entrance onto the historical stage of a different mode of legitimation of new kinds of imperial politics: a modern, secular, technological affirmation of power and order at national and global levels. On one hand, there emerged the radi- cally modern revolutionary ideologies of Communism, Fascism and National-Socialism; on the other, there emerged the consolidated economic and political power of a new self-confident Liberalism in the shape of a global and historically decisive United States.

Jünger was fully aware of the profound differences between the particular contexts of various combatant states before and after the war. He observed closely the political agencies and systems of ideas, first in Communist Russia, then in Weimar Germany and Mussolini's Italy, followed by the rise of NationalSocialism. He understood that, despite claims to a unique calling, they sought historical sustenance in a common ground characterised by an even more intense drive to global expansion and belligerence:

When we consider the world as it has emerged from the catastrophe - what a unity of effect, what measure of strict historical consistency! [...] The old bells of the Kremlin have been tuned to the Internationale. In Constantinople, children spell the old arabesques of the Koran in Latin script. In Naples and Palermo, Fascist police rule the affairs of southern life according to the principles of modern traffic. (Jünger, 1930b: 26-27)

For Jünger, the common call was to 'total mobilisation': the channelling and management of the entire force of the nation, the 'people', or the 'proletarians of the world', into a process of production and self-production driven by the highest possible level of technological and managerial order. The legacy of the war was a new sentiment of power triggered by the colossal quantities of destructive material and energy unleashed on the battlefields of Europe. It revealed, in his view, the integration of war in a vision of power characterised by the rational and progressive organisation and manage- ment of existence through the 'extension of the perspective of utility into the infinite' (Jünger, 1930b: 13). The 
continuous increase in control and mastery over the production of energy was becoming the primary political platform for promises of ultimate emancipation from any constrain- ing bonds to either nature or transcendence. Aligning social, political and economic orders to this principle captured the essence of his concept of mobilisation, which Jünger understood as that kind of thinking driven relentlessly to seize matter, movement and force through the formalism of technoscience, and subject them to human organisation. 'Progress' had already been mobilised by all sides as the most effective propagandistic theme during WWI: 'the special nature of this great catas- trophe [was] that in it, the genius of war was penetrated by the spirit of progress' (Jünger, 1930b: 11). None of the other faiths could muster the political and cultural force that progress could:

Perhaps these slogans bore a crude and tawdry colour, but there can be no doubt about their effectiveness; they recalled the coloured rags with which the prey is directed towards the guns. (Jünger, 1930b: 17)

A new combination of agencies, civilian and military, public and private, mobilised across Europe, expressed not just the willingness to experiment with increasing means of destruction but also the transformation of war into a domain in which 'new problems extorted fresh spasmodic exertions', into an open and terrifying laboratory. 'The capacity for the speedy development of a large programme [of armament made] this war differ from all previous ones in that it [was] not fought out on one fixed plan' (Jünger, 1930a: 137) but on the assumption that all resources have to be directed towards, and managed for, the war:

A mobilisation of such extent could not be foreseen by human understanding. ... In the course of the war this process intensified: as examples, we can cite the planned exploitation of raw materials and subsistence means, the conversion of employment relationships into military ones, civil-guard duty, the arming of trade vessels, the unexpected extension of the authority of the general staff, the 'Hindenburg programme', Ludendorff's struggle to amalgamate military and political command. (Jünger, 1930b: 14-15)

'Programme after programme' of organisational and technological experimentation, 'whether justified or exploded by events', took the form of 'a test of endurance that taxes every section and every resource of the nations involved' (Jünger, 1930b). This foreshadowed the form of future wars: inextricably linked to the demands of increasingly total and centralised organisa- tion of the production of energy. In this context, the figure of Walter Rathenau is significant in Jünger's critique because it embodied the logic of 
total mobilisation as an early exponent of the origins of 'the military-industrial complex'. Rathenau, a businessman, leader of AEG, initiated (on 13 August 1914), and headed, the first integrated governmental body seeking to manage the entire German economy and align it to the war effort: the Kriegsrohstoffsamt (KRA - the Office for Raw War Materials). Rathenau (1917) saw it as a step towards his vision of the future: a totalising, state-led, 'public economy' (Allgemeinwirtschaft), expressing collective destiny beyond politics:

War destroys the independence of the private economy and prepares future forms of the economy by making it possible that the economic interests of a civilized state are not affairs of the individual, but the concern of all. ... The collective spirit of the nation, however, like every other spirit, expresses its vitality visibly through growth and increase. Growth means will to annihilate the other, for life lives from death. (pp. 247-248, 295-296)

His famous dictum - 'not politics, but the economy is our destiny' - meant that the integration of state and private economic interests had to become the fundamental principle for the manage- ment of all economic activities not simply as a matter of defence but as the essential source of a nation's power. For Jünger, complete integration and organisation in the name of power were not the whim of a single figure; total mobilisation, as public necessity, was only just commencing. War had indeed shown itself to be a productive process, an integral part of the machinery of power. War's entanglement with 'national vitality' was becoming central to the political, economic, social and cultural imagination:

The organising force and the grip of industry, the work force of the mass, the national enrolment of finance, the superiority of science and its intimate binding to life itself, the development of culture as a whole - who could enumerate all that will be made to come together? (Jünger, 1930a: 137)

This insight was echoed at the end of the century in Alvin Toffler and Heidi Toffler's (1995) account of the coming 'third wave war' (pp. 73-93) in remarkably similar terms to Rathenau's: 'the way we make wealth' will shape the outlines of future war, even though the authors seemed una- ware of the history of their interpretation (Toffler and Toffler, 1995: 64-65). Following WWI, new political regimes, from Left to Right, embraced total mobilisation as a call on all potential resources (the French slogan was, literally, 'énergie potentielle') to stand at the state's command as guardian of 'people's security', the new res publicum, in times of triumphal peace as well as war. Peace, the pre-condition of freedom, becomes thus dependent on a permanent programme of readiness of society for defence. For Jünger, WWI had been but a preparation for ideologies relying on perma- nent 
readiness for defence as the systematic ground of political programmes compulsory for any 'free' nation. Political systems emerging from 1917 to 1919 (and onward) succeeded in making total mobilisation appear as indispensable for securing the space for national 'progress' and 'devel- opment'. This profound change of political culture meant that, under the 'undisguised mask of Reason', could be found the legitimation of a new kind of absolute state power which licensed a very concrete political programme:

The task of total mobilization is the conversion of life itself into energy, as it manifests itself in business, technology, and transport, in the whirring of wheels, or in fire and movement on the battlefield. It is thus related to the potency of life itself. (Jünger, 1981: 109)

Total mobilisation can be articulated 'in the name of the people', as protection and affirmation of life, and it helped Jünger understand why total mobilisation claiming, on one hand, the univer- sality of reason, could become, on the other hand, an expression of nationalism. The rational organ- isation of life becomes a national necessity because it can be justified as indicator of national success and progress. For Jünger (1930b), however, it became a licence to

... intrude in ways hitherto thought inconceivable; it spins around an artificial circular dialectic, but its movement unfolds on a simple level. It begins to subordinate peoples to forms which are no different from those of an absolute regime, with much reduced allowances for freedom and comforts. In many cases, the humanitarian mask has been almost stripped away, to be replaced by a half-grotesque, half-barbaric fetishism of the machine, a naive cult of technology - especially where there is no direct, productive relationship to those dynamic energies for which the destructive, triumphal course of long-range artillery and bomb-loaded fighter squadrons are only the military expression. (p. 27)

Total mobilisation, therefore, does not indicate a military phenomenon, nor is it a quantitative concept to be understood in the military terms of universal conscription. Rather, mobilisation cap- tures the quality of power when it demands the concentration of the energies of the 'people' into a self-preserving unity, while its total character 'will only occur when the image of military processes will be preordained for the order of the situation of peace' (Jünger, 1930b: 15). The essence of total mobilisation is its 'measure of organisational thinking which is only an intimation of that higher mobilisation which the times are pressing upon us' (Jünger, 1930b: 22). It indicates why modern existence could be managed, explicitly or implicitly, in totalising and totalitarian terms, in peace as much as in war. Total mobilisation is not one process or another, one place or another, one moment or other. It represents a new rhythm through which power 
claims universal mastery in the organisation and rationalisation of production and destruction alike:

In this lies the secret of that brutal and unexpected speed with which America raised up whole armies and arsenals out of the ground itself once war was declared, and this also explains why the American engineer quickly proved himself to be readily adaptable to the Russian planned economy in its almighty transformation of an uncultivated soil. (Jünger, 1981: 148-149)

Jünger's argument is that progress and development provide a new political vocabulary in which existence appears both as a permanent source of conflicts and tensions, and as the theatre of increasingly rational, progressive solutions. The frenetic pace imposed by the process of mobilisa- tion is therefore not limited to emergencies but tends to become the rhythm of all existence and change is always urgent, always imperative, always optimistic. WWI had not been simply an extraordinary event, but a threshold beyond which the capacity to fuse organised destruction to organised production began to crystallise into the 'normal' situation:

Many instances can be mentioned in this sense: it is enough to consider our own life fully unleashed in its merciless discipline, with its smouldering and glowing industrial districts, with the physics and metaphysics of its traffic, its motors, airplanes, and gigantic cities - to sense, with a feeling of horror mixed with yearning, that not a single atom is not at work here, and that we are ourselves most deeply bound up within this raging process. Total mobilization is far less something to be carried out, than something which carries itself out; it is, in war and peace, the expression of the mysterious and inescapable demand to which life in this age of the masses and machines subjects us. That is why each individual life becomes, ever more clearly, the life of a worker; and why the wars of the knights, the kings, and the bourgeois are followed by wars of workers - wars of whose rational structure and mercilessness the first great twentieth-century conflict has given us an omen. (Jünger, 1930b: 15-16)

Does the question of total mobilisation remain actual today when terrorism is seemingly always capable of penetrating ordered social spaces in utterly unexpected ways? If the end of the Cold War appeared to herald the hope of almost complete de-mobilisation and the possibility of envisaging global peace, the 'war on terror' brings to the fore the frailty of peace and security, the persistence of global tensions and of blocks whose antagonisms have the potential to generate conflicts of more terrifying scope given the technological means of destruction available. But terrorism has also revealed, perhaps even 
more intensely, how rapidly the political stage turns to measures of internal total mobilisation and control. This is why Jünger's thesis seems worth revisiting today, when war appears again as indispensable to the functioning of 'peaceful' societies:

We see therefore how methods of rearmament are already tailored for total mobilisation. We can mention here phenomena like the increasing curtailment of 'individual freedom', which admittedly is always questionable. We encounter this assault, whose tendency aims to deny anything that cannot be regarded as a function of the state, first in Russia and Italy, but then also with us; and it is foreseeable that all countries making global claims will do the same in order to unleash new kinds of forces. (Jünger, 1930b)

This passage suggests how subtly the dialectic of the 'risk society' (Beck, 1992, 1999,2009 ) has developed as a permanent feature of the modern way of life. The wars of the 21 st century show the extent to which the abhorrence of risk has been integrated in contemporary political discourses. In the blink of an eye, states convert the protection of freedom into totalising forms of control of freedom itself, and thus licence themselves to wage war. The 'war on terror', one of the central justifications for military intervention, offers numerous examples. After the New York attacks in 2001, one of the central tenets of US policy and legislation was the establishment of new forms of comprehensive internal surveillance entailing a substantial re-definition of the sphere of individual privacy. The US Patriot Act of October 2001, entitled 'Uniting and Strengthening America by Providing Appropriate Tools Required to Intercept and Obstruct Terrorism', legitimised, in the name of freedom, the erosion of fundamental rights. Personal liberty, free speech, free association, legal representation and speedy public trial (for which Guantanamo Bay and extraordinary rendi- tion are eminent illustrations) - all became, in the United States, targets of a secretly revived National Security Agency and of a (very public) new Department of Homeland Security. The inter- national belligerence of the United States and its allies, with or without secure legal and diplomatic grounds, but always legitimated by any reference to terror, built up to the catastrophes now unfold- ing in so much of the Middle East.

In turn, denouncing vaguely defined universal 'enemies of Islam' and seeking their annihilation, terror's main weapon, the suicidal group or individual, appears as a far more primitive technologi- cal and organisational instrument. Able to act on just about any target, at any point, with the banal- ity of a cooking pot or an inconspicuous truck, terror in the 21 st century is nonetheless far from 'primitive': its actions are entirely dependent on technologies of communication and mobility (mobile telephony, Internet access, and aviation). 
Moreover, it is the capacity of terror to seize the power of danger and make it appear omnipresent that licences a new kind of 'silent', and increas- ingly comprehensive, internal total mobilisation of citizenry, especially at the level of communica- tions. The attacks in France and Germany in 2015-2016 have also brought to the fore calls to mobilisation not heard in Europe for seven decades. In France, for example, the number of indi- viduals seeking to join the army quintupled in November 2015 after the Paris attacks to around 1500 per day. After the Bastille Day attacks in Nice, the President announced the formation of a new National Guard (disbanded in 1872) and called again for French 'patriots' to enlist. In August 2016, the German interior ministry presented a proposal to the cabinet to reinstate compulsory national service and explore the formation of new structures of civil defence to support the army; discussions about the possibility of deploying soldiers on home soil followed the Munich shootings on 22 July.

\section{The belligerence of peace: The Worker. Dominion and Form (1932)}

Jünger's insights about the dangers of contemporary war emerge with more clarity in the volume which synthesised his critique of modernity in its most developed structure. The volume on The Worker is the systematic expression of Jünger's thinking about the impact of world war upon the context of the 20th century (Jünger, 1981). It examines the shape of an emerging global political context characterised, as Arendt (1946) later argued, by 'expansion, the political brain child of the businessman in despair, conceived as limitless and thought of as the leading new principle of the nation's foreign policy' (p. 603). For Jünger, to understand the new 'merciless' rational, techno- logical, scientific and industrial war presupposed a meticulous interpretation of the diffusion of modernity's conception of power throughout social, economic and political discourses. Thinly veiled by claims to pursue peace, the escalating ambitions of new political systems could hardly conceal their main purpose: the limitless expansion of their grip on power. This marked, for Jünger (1930b), the essence of total mobilisation: 'an act through which the widely ramified and richly veined currents of modern life can be marshalled, with a single flick of the switch, into military energy' (p. 14). This comportment towards power inaugurated a new epoch of armed conflict on an unprecedented scale anticipated by Jünger as a central dimension of the unfolding of global politics in the coming century. It indicated the true depth of the dangers signalled by the war: a monstrous situation behind which began to operate, with regularity, a permanent conflictual state of affairs. Total mobilisation would not cease when military campaigns ended; 
rather, it would become the mode in which modern life will come to be ordered:

Thus the image of war as armed action is flowing increasingly into the intensified image of a gigantic work process. Alongside the armies meeting on the battlefields, there arise the modern armies of logistics, of alimentation, of the arms industry - the army of work in general. [...] This absolute channelling of potential energy, which transformed industrial states into volcanic forges, is perhaps the starkest indication of the dawn of the age of work. (Jünger, 1930b)

His argument was that 'the Great War was fought not only between two groups of nations but also between two epochs' (Jünger, 1981: 27). Unprecedented possibilities of mobilisation inti- mated by the war had grown into a new logic of politics. The acquisition and expansion of power became the principle governing all the spheres of human action. He sees this relatively rapid shift unfolding in countries as different as Russia, Italy and Germany, the United States and France. What they had in common, it seemed, was the formation of a new sense of imperial construction in the name of the 'people', a category no longer referring to any single individual but to the pro- tection of individuality as such, whose permanent assertion becomes the defining platform for incontestable political legitimation. He shows how individuality, translated in a language seeking to appeal to the productive core of society, explains the ways 'in which all parties today designate themselves as workers' parties' (Jünger, 1981: 33). The claim to represent and protect society's core by affirming its productive energies found fertile ground in politics and the economy; it was leading, in Jünger's view, to the formation of a new rhythm of 'normal' life. But what was the underlying nature of this process of normalisation?

In The Worker, he pursues this question at multiple levels: in the emergence of a new politics of power expansion, as well as in a new understanding of the economy which has to be ready to mobilise against dangers that always threaten society and its progressive course. Besides the

political and the economic, he explores the twin themes of danger and mobilisation through the technological, social, cultural, artistic and propagandistic diffusion of a permanent sense of urgency to plan, organise and manage against danger. Jünger's analysis is one of the earliest to seize upon a theme which has since become central to national and global politics. The politics of security follows the subtle dissemination of a general sentiment that life is surrounded by the permanent potential of risks to be systematically avoided and eliminated. The state is called upon to undertake whatever is necessary to secure existence itself by the means of increased defensive resources. This major shift made clear, Jünger thought, that preparing for war 
would become one of the indispensable tasks of states who will always be able to invoke security as an ultimate and unassailable public good:

... we must grasp the bourgeois [individual] as the one who sees security as a highest value and conducts his life accordingly.

The supreme power through which he sees this security guaranteed is reason. The closer he finds himself to its centre, the more the dark shadows which conceal what is dangerous melt away, so that, sometimes when hardly a cloud seems to darken the sky, it fades into the distance.

Yet danger is always present; it is forever searching, like an element, to burst through the dams with which order surrounds itself, and - according to the laws of a secret, yet incorruptible mathematics - it becomes more threatening and deadly to the same extent that order believes it has expelled it from itself. (Jünger, 1981: 24)

Self-assured by a 'progressive' faith in the possibility of the completion of its project, the main effect of the politics of security is to force upon the world the principle of reason as the only legiti- mate basis for the organisation of both space and time, of both production and destruction:

... the ideal condition of security, towards which progress strives, consists in the universal dominion of bourgeois reason which seeks not only to diminish the sources of danger, but ultimately to run them dry. (Jünger, 1981)

Disguised as measures for the protection of security, offensive actions acquire unquestionable legitimacy. The rhetoric of military campaigns discovered a new propagandistic register that has now become the established idiom of international security politics:

So it has become possible for wars to be waged nowadays without anyone noticing, because the stronger side prefers to describe them as something like peaceful penetration, or police action against bands of robbers - wars which exist in reality, but not in theory. (Jünger, 1981: 96)

To these, the intervening decades have added 'humanitarian interventions' and 'humanitarian bombing', 'surgical strikes', 'nuclear deterrence', 'peace-keeping operations' or 'international policing operations'. On one hand, Jünger seeks to understand the movement towards a new world conflagration created by the failure of the peace settlement of 1919:

From now on, however, even the secured precincts of order itself ignite like gunpowder 
that has long lain dry, and the unknown, the extraordinary, the dangerous does not only become the familiar - it becomes permanent. After the armistice, which only appears to end the conflict, but in truth surrounds and undermines all the borders of Europe with whole systems of new conflicts, what remains is a situation in which catastrophe appears to be the a priori of a transformed thinking. (Jünger, 1981: 28)

On the other hand, he signals a deeper and more significant aspect of the consolidation of war at the heart of emerging political philosophy. Jünger points out the permanent anxiety, the diffuse fear of any potential loss of control, that was shaping the modern soul. Modernity seems, among other features, to be intoxicated with the new feeling of liberation from constraints and discom- forts. Defending life's new conquered comforts, a life lived 'in a kind of pre-war belle époque' (Jünger, 1981), indicates a specifically modern aspiration to limitless security as prerequisite of freedom. The political ideologies which followed in the wake of WWI found in this theme the most fecund aim and justification for permanent readiness to wage war against any perceived danger:

And there is no mistaking the weakness behind slogans like 'peace and order', 'national community', 'pacifism', 'economic peace', 'agreement', in short: behind the last appeal to the reason of the Nineteenth Century - they belong to the vocabulary of restoration, whose constitutions resemble peace treaties spread like thin, temporary veils over an intensified progression of the rearmament. (Jünger, 1981)

Reading The Worker today would show, perhaps even more than eight decades ago, its acute relevance with regard to the theme of this special issue: namely, that the waging of war finds abun- dant cover under causes formulated in the name of safeguarding the space of modern comforts, of universal rights and limitless security. In other words, the text opens up once again some of the more fundamental problems connected to the licensing of violence in the name of organising the world, of managing it in such a way that unlimited freedom is secured for the very specific 'way of modern life'. To this end, the drive to manage always contains within its essence the demand to drive out all that appears contrary to it. Securing the organised character of the world, and waging war in the name of its protection, is not simply a reflection of the nature of things as they are. Rather, Jünger saw it as the imposition of an ethical programme whose central demand is that all social and political entities ought to follow a common order. The drive to total organisation is thus, for him, the drive for the preservation and expansion of a particular order of power. This order's principle, in Jünger's interpretation, is that freedom is realised only when the autonomy of calcula- tive reason prevails. 


\section{Concluding remarks}

The texts presented here highlight the dangerous tendency towards war in the century that followed WWI. For Jünger, new relationships between agencies, technologies, processes, as well as the space and ethos of war had profoundly changed its nature and heralded a historical phase in which war would become an even more enormous and intense enterprise. The technoscientific and politi- cal authority of reason would bring war, Jünger anticipated, under the same principles of manage- rial, material and ethical ordering of industrial mass-production. However, the gravest danger in a world re-enchanted by technological marvels and seduced by the power of reason was always going to be the inevitable thoughtlessness accompanying such total confidence. If technological rationality will be used for the moral and legal justification for war, then there will be no rational limit for the necessity of arming for defence: 'it is logical that neither human endeavour nor bil- lions are spared. The race is run over the longest distances over the minutest time gains' (Jünger, 2003a: 73).

The ensuing century, operating through the universal claim to defend 'freedom' and 'peace', has been engaged in a colossal race to expand the technoscientific apparatus of security. Jünger's cri- tique is one of the earliest to show how, in the modern technological world, war becomes converted into a process of continuous production of armaments. No conflict, local or global, is decided by a few short battles; security is not just an episode, but a continuous process demanding a collective

national performance. Its prerequisite is that nothing is left out from the total plan of defensive mobilisation, that everything is 'known' and utilised, guarded and watched. Jünger (1981) asks, in 1932, 'And, by the way, has not the science of our time already begun to see atoms no longer as the smallest particles, but as forms?' (p. 16). Drawing theoretical physics into the politics of power expresses the fascination with the possible release of 'endless' energy under human command. The atom did indeed become the instrument for a politics able to claim the only ultimate power human- ity does possess: that of precise, calculable, unmistakeable self-destruction. The nuclear arms race was, and remains, the clearest expression that destruction had become a race for production, rather than a 'battle' in any traditional sense. Concentrating the highest energies of reason, science and technology, the aim of the military system had changed subtly but radically:

Now, we no longer point out arsenals, but only their keys. The mere display of such a key can be a deep deterrent. Temerity too shifts to another place; it is transferred onto the experiment itself. (Jünger, 2003a: 73) 
This passage seems to reflect the tone of the more recent conflict between North Korea and its enemies: a performative war of words and experiments whose aim is to be no more than a display of keys to power.

Finally, one of the important questions is whether Jünger's texts are strictly confined to analyses of war. As this review may have already suggested, Jünger's critical range extends far beyond war itself. The core themes that connect his investigations to central concerns in the analysis and study of organisations and management are those of technology, reason, power and knowledge. In particular, he examined how the permanent invocation of rationality allows the consolidation of the liberal state to unfold behind the mask of the protection of freedom. Jünger attempted to dissect and understand how social, political and cultural tensions inherent in systems of rational management are manifest in the spheres of production, exchange and consumption. These lines of inquiry have been of constant interest in the development of organisation studies. Jünger's works are therefore part of a continuous and connected line of thinkers who placed at the core of their studies of insti- tutional orders the questions of technology, rationality and power as elements defining the outlines of this domain of inquiry.

\section{Notes}

1. This exact expression appears not only in Jünger's texts but also in Henry Barbusse's (2015) Le Feu (orig. 1917) and, a decade later, in Arnold Zweig's (2000) The Case of Sergeant Grischa (orig. 1927).

2. All the excerpts from this essay are translated from German by the authors. (An English translation has been published in The Heidegger Controversy: A Critical Reader, ed. by Richard Wolin, trans. by Joel Gold (Cambridge, Mass.: MIT Press, 1993), pp. 122-39. However, at times, the published version bypasses some of the nuances essential to Jünger's argument.)

\section{References}

Arendt, H. (1946) 'Expansion and the Philosophy of Power', The Sewanee Review 54(4): 601-16.

Barbusse, H. (2015) Le feu. Paris: Larousse.

Beck, U. (1992) Risk Society: Towards a New Modernity. London; Newbury Park, Calif.: Sage Publications.

Beck, U. (1999) World Risk Society (1st ed.). Oxford: Polity.

Beck, U. (2009) World At Risk (2nd ed.). Cambridge: Polity.

Benjamin, W. (1979a) One-way Street and Other Writings. London: NLB.

Benjamin, W. (1979b) 'Theories of German Fascism: On the Collection of Essays War and Warrior, Edited by Ernst Jünger', New German Critique 17(Spring): 120-28.

Chief of the Defence Staff (2014) UK Defence Doctrine. Shrivenham: Development, Concepts and Doctrine Centre. 
Defense One (2016) 'Army Warns that Future War with Russia or China Would Be "Extremely Lethal and Fast", Defense One. Retrieved October 18, 2016, from http://www.defenseone.com/threats/2016/10/ future-army/132105/

Heraclitus of Ephesus (1979) The Art and Thought of Heraclitus: An Edition of the Fragments with Translation and Commentary by Charles H. Kahn. Cambridge: Cambridge University Press.

Hervier, J. (1978) Deux individus contre l'histoire: Pierre Drieu la Rochelle, Ernst Jünger. Paris: Klincksieck.

Hervier, J. (2014) Ernst Jünger: Dans les tempêtes du siècle. Paris: Fayard.

Joint Publication 1 (2013) Doctrine for the Armed Forces of the United States.

Department of Defence. Retrieved from

http://www.dtic.mil/doctrine/new_pubs/jp1.pdf

Jünger, E. (1929) Feuer und Blut: Ein kleiner Ausschnitt aus einer grossen Schlacht, 4th ed. Leipzig: Reclam.

Jünger, E. (1930a) Copse 125: A Chronicle from the Trench Warfare of 1918, 1st ed. London: Chatto \& Windus.

Jünger, E. (1930b) 'Die totale Mobilmachung', in E. Jünger (ed.) Krieg und Krieger, pp. 930. Berlin: Junker und Dünnhaupt Verlag.

Jünger, E. (ed.) (1930c) Krieg und Krieger. Berlin: Junker und Dünnhaupt Verlag.

Jünger, E. (1930d) The Storm of Steel: From the Diary of a German Storm-troop Officer on the Western Front. London: Chatto \& Windus.

Jünger, E. (1970) On the Marble Cliffs. Harmondsworth: Penguin Books.

Jünger, E. (1981) Sämtliche Werke, Band 8. Essays II. Der Arbeiter. Maxima-Minima.

Stuttgart: Klett-Cotta Verlag (forthcoming English translation: Evanston, IL:

Northwestern University Press, 2017).

Jünger, E. (2001) Politische Publizistik, 1919 bis 1933. Stuttgart: Klett-Cotta Verlag.

Jünger, E. (2003a) An der Zeitmauer. Stuttgart: Klett-Cotta Verlag.

Jünger, E. (2003b) Storm of Steel (new ed.). London: Allen Lane.

Jünger, E. (2015) Sämtliche Werke - Band 9: Essays I: Betrachtungen zur Zeit. Stuttgart:

Klett-Cotta Verlag. Kiesel, H. (2007) Ernst Jünger. München: Siedler.

MacMillan, M. (2013) The War That Ended Peace: How Europe Abandoned Peace for the First World War. London: Profile Books.

Malesevic, S. (2010) The Sociology of War and Violence. Cambridge; New York:

Cambridge University Press.

Nietzsche, F. W. (1968) The Will to Power. New York: Vintage Books.

Nietzsche, F. W. (2005) The Anti-Christ, Ecce Homo, Twilight of the Idols, and Other

Writings (ed A. Ridley and J. Norman). Cambridge: Cambridge University Press.

Paetel, K. O. (1949) Ernst Jünger. Weg und Wirkung. Eine Einführung. Stuttgart: Ernst Klett Verlag.

Rathenau, W. (1917) Von kommenden Dingen. Berlin: S. Fischer Verlag.

Schöning, M. (ed.) (2014) Ernst Jünger-Handbuch: Leben, Werk, Wirkung. Stuttgart: J.B. Metzler Verlag.

Toffler, A. and Toffler, H. (1995) War and Anti-War: Making Sense of Today's Global Chaos. London: Warner Books.

Wells, H. G. (1914) The War That Will End War. London: Frank \& Cecil Palmer.

Zweig, A. (2000) The Case of Sergeant Grischa. London: Prion Books Ltd. 


\section{Author biographies}

Bogdan Costea is a professor in the Department of Organisation, Work \& Technology in Lancaster University Management School. He explores how core philosophical arguments about the nature of the self, meanings and implications of work, and human organisation reappear encoded in the contemporary culture of managerialism. Together with Laurence P. Hemming, he is co-author of the first English translation of Jünger's The Worker.

Kostas Amiridis is a lecturer in the Department of Organisation, Work \& Technology in Lancaster University Management School. His research focuses on the historical development of managerialism and the philo- sophical dimensions of business and capitalist ethics. 